\title{
NEW SERVICE DEVELOPMENT AND ITS FINANCIAL PERFORMANCE IN IRAN BANKING INDUSTRY

\author{
Shahram Ghahramani ${ }^{1}$, Mehran Rezvani ${ }^{2}$, Farajollah Rahnavard ${ }^{3}$ \\ ${ }^{1}$ Institute For Management And Planning Studies (IMPS), Tehran, Iran \\ 1sh.ghahramani@imps.ac.ir \\ ${ }^{2}$ Faculty of Entrepreneurship, University of Tehran, Tehran, Iran \\ 2m.rezvani@ut.ac.ir \\ ${ }^{3}$ Institute For Management And Planning Studies (IMPS), Tehran, Iran \\ 3f.rahnavard@imps.ac.ir
}

\begin{abstract}
New service development is increasingly becoming one of the most important aspects of business strategy in both service and non-service industries. In todays economical world where has become more service oriented, it can be said that the new service development (NSD) is one of the most important components of growth in dynamic environments. As new proposals lead to an increase in income, profit and develop in market share. The aim of the study was to survey new service development and factors affecting its financial performance in banking industry. In terms of research philosophy this is a demonstrative, in terms of research purpose and direction it's a practical and descriptive, and in terms of research implementation strategy it's a survey research that has been executed in cross-sectional time period. The purpose of the research sampling was to examine the new services, which are provided in the various banks. Stratified probability sampling method used is based on 150 questionnaires in headquarters and branches of different banks, which are located in Tehran city, and 118 questionnaires were gathered. Data obtained from the questionnaires were analyzed in both descriptive and inferential level by using SPSS version 21 and Lisrel 8.8 Windows version. Structural equation modeling techniques (confirmatory factor analysis and structural analysis) have been used to test the research hypotheses. Results of the research showed that cross-functional teams and learning orientation have positive impact on the new service marketability. And indirectly have a positive impact on the financial performance of new service. Customer involvement and learning orientation have positive impact on the new service launch preparation, but the effect of new service launch preparation on new service financial performance has not been proved in the current study.
\end{abstract}

Key words: New service development (NSD), Cross-functional teams, Front line employees, Learning orientation, Financial performance.

Academic Discipline And Sub-Disciplines: Management,Service Management

METHOD: Survey Study

\section{Council for Innovative Research}

Peer Review Research Publishing System

Journal: International Journal Of Management \& Information Technology

Vol . 10, No 5

editorsijmit@gmail.com

www.ijmit.com 


\section{INTRODUCTION}

In the recent years, numerous researches have been done in relation to the development of new products, but new service development (NSD) has experienced less consideration. New service development is becoming one of the most important aspects of business strategies Menor et al, (2002). And in today's world that has become more service-oriented, companies and organizations have felt need for competing on the new service basis Zeithaml and Bitner (2000).

The main challenge in the new service development of banking products is appropriate organization transformation in the face of technological changes. The most important weakness of our country's (Iran) banking system is crating local and new products and services. On one hand, familiarity with various products at the international level is low, and on the other hand some strange products are produced in the country, which are although remarkable and unprecedented in terms of technology, but in terms of financial and banking does not have much added value and merely generate cost or ruin the new opportunities in this field. According to the pioneering interest of people about the electronic banking services, demand on the new services has been enhanced, so the banking system should has the ability to respond to these new demands on the market. Also there is a lot of literature about NSD but you cannot find any of them, which surveys the theories, and models of it comprehensively in banking system.

\section{REVIEW}

Table 1: The research literature of NSD variables

\begin{tabular}{|c|c|}
\hline Variable & Research Literature \\
\hline $\begin{array}{l}\text { Cross-functional } \\
\text { teams }\end{array}$ & $\begin{array}{l}\text { Schilling and Hill, (1998); Griffin, A. and Page, A.L. (1993); Cooper, R. G., } \\
\text { E. J. Kleinschmidt. (1995); Olson, E. M., O. C. Walker, and R. W. Ruekert, } \\
\text { (1995); Davenport, T. H. (1993); Terrill, Craig A. (1992); Gallouj, F. and } \\
\text { O.Weinstein (1997) ; Pisano, G. P. (1997) ; Brown, S.L. \& Eisenhardt, } \\
\text { K.M. (1995); Ancona, D.G. and Caldwell, D.F. (1992); Froehle et al, } \\
\text { (2000);Sethi et al, (2001); Edmondson, (1999); Papastathpoulou et al, } \\
\text { (2001); Froehle and Roth, (2007); Lovelock et al., (2001); Keller, Robert } \\
\text { T. (2001). }\end{array}$ \\
\hline Front-line Employees & $\begin{array}{l}\text { Tajeddini \& Trueman,(2008b);Horace and Hartline, (2010) ;Schneider and } \\
\text { Bowen, (1984); Daniel \& Darby, (1997); Albrecht \& Zemke, (1985); } \\
\text { Hennig-Thurau, (2004); Sergeant \& Frenkel, (2000); Bateson, (1992); } \\
\text { Daniel \& Darby, (1997); Lovelock, (1981). }\end{array}$ \\
\hline $\begin{array}{l}\text { Customer } \\
\text { Involvement }\end{array}$ & $\begin{array}{l}\text { Day \& Wensley, (1988); Kotler \& Armstrong, (1994); Ruekert, (1992); } \\
\text { Tajeddini \& Trueman, (2008b); Tajeddini, Trueman, \& Larsen, (2006); } \\
\text { Dolfsma, (2004); Ennew \& Binks, (1996); Tajeddini, (2011); Alam, (2002); } \\
\text { Magnusson,et al, (2003); Bowers, (1989); Edvardsson and Olsson, } \\
\text { (1996); Melton and Hartline, (2010); Grönroos, (1982), (1983); Alam \& } \\
\text { Perry, (2002); Kelly, (1992); Hennig-Thurau, T., \& Thurau, C., (2003); } \\
\text { Dowling, (1993); Kärkkäinen et al, (2001); Edvardsson et al., (2000); } \\
\text { Vermeulen, (2004); Akamavi, (2005a), Johne, Axel, and Chris Storey. } \\
\text { (1998). }\end{array}$ \\
\hline Learning Orientation & $\begin{array}{l}\text { Baker \& Sinkula, (1999); Tajeddini, (2009); Sullivan, (2000); Huber, } \\
\text { (1991); Slater \& Narver, (1995); Duncan and Weiss,(1978); HennigThurau } \\
\text { \& Thurau, (2003); Calantone et al, (2002); Sethi et al, (2001); Nembhard } \\
\text { and Edmanson, (2009); Baker and Sinkula, (2007); Tajeddini, (2011). }\end{array}$ \\
\hline Service Marketability & $\begin{array}{l}\text { Magnusson et al., (2003),Melton \& Hartline, (2010); Melton \& Hartline, } \\
(2012)\end{array}$ \\
\hline Launch preparation & $\begin{array}{l}\text { Melton \& Hartline, (2010); Melton \& Hartline, (2012); Michael, (2010); } \\
\text { Booz et al.,(1982) }\end{array}$ \\
\hline $\begin{array}{l}\text { Financial } \\
\text { Performance }\end{array}$ & $\begin{array}{l}\text { Staelin, (1995); Terninko, Zusman, \& Zlotin, (1998); Dooley and Sullivan, } \\
\text { (2007); Dolfsma, (2004); Tajeddini, (2009); Ottenbacher et al, (2006); } \\
\text { Menor, Mohan, \& Sampson, (2000); Goldstein, Johnston, Duffy, \& } \\
\text { Rao,(2002); Riel and Lievens, (2004); Varadarajan and Jayachandran, } \\
\text { (1999); Cooper and Edgett, (1996); Matthing et al., (2004); Johne, A., \& } \\
\text { Storey, C. (1998); Menor, L. J. and A. V. Roth,(2008); Ottenbacher, } \\
\text { (2001); Griffin, A. and Page, A.L. (1993). }\end{array}$ \\
\hline
\end{tabular}




\section{Service}

Service is one of the key fundamentals of every profitable business today. Developing service in a successful way is essential for the service organization's survival in every competitive market. In a service-based economy, companies are trying to introduce new services and products to make value for existent customer and attract more new customer in order to boost their competitiveness Edvardsson and Hay (2006).

Industrial service products compose important part of economics. In manufacturing sectors, new service products demonstrate a principal source of company's growth. Nonetheless product's innovation in industrial service area has been broadly neglected De Brentani (1991).

Despite the significance of successful new service development, the knowledge to achieve this success is limited. The rate of success in new service development projects in average is 58 percent, in other words from every ten NSD project, four of them fail. Hence, if the service companies and organizations typically seek to improve their low success rates, developing their knowledge of the critical factors affecting innovation efforts is necessary (Dalton et al, 2009).

During the new service development, four features of services should be considered such as: intangibility, inseparability, variability and perishability. This means that services cannot be checked before they even purchased, and it cannot be stored. Thus the nature of a service influences its development and management (Shekar, 2007).

\section{Innovation in Services}

A large part of business innovation efforts are related to new service development (Howells, 2000). All of the innovation definitions include the implementation and development of a "new thing". Lovelock (1984) argued that the word "new" is one the words which is used widely in marketing dictionaries.

Avlonitis et al (2001) have clarified that service innovation can be related to variations in different dimensions such as innovation in service concept, relationship with customer, delivery systems and 4.technological measurements.

Innovation in service concept includes changes in the characteristics of the service itself and this aspect has been diagnosed in many cases. Innovation in services can also be associated with customer interaction. Service offerings are increasingly supplied to the market, which produced by the specific method of customer. Characteristics and demands of existing and potential customers, raises a service company to make adjustments in communication and interaction with customers (Van der Aa and Elfring, 2002).

\section{NSD Definitions}

Today, new service development (NSD) has become as a necessity for the survival and competitiveness of service firms (Alam, 2006; Johnson et al., 2000; Sigala and Chalkiti, 2007).

New service development (NSD) includes providing developments such as financial services, healthcare, telecommunications services, information services, leisure and travel services, facility management services, educational services and legal and advisory services. These offers can be provided for both consumers and businesses. In the recent years, a huge body of specialized literature has been accumulated that focus on the marketing and development of the services separate from products (Johne and Storey, 1996).

NSD refers to the overall process of developing new service offerings from idea production to the market readiness (Goldstein et al. 2002). Johnson (2000) defines NSD as the process of creating, developing and launching new services in the market.

\section{NSD Necessity}

According to the Palmer (2001) organizations need to develop new services for several reasons:

1. When one of the services of the organization has matured, and there is the possibility of entering to the decline phase, new service development can alter the sale process of the company.

2. Making new services for utilizing from the unused capacities which exist in the service organization.

3. The new service will reduce the risk of which the company's revenues become dependent to one or more products.

4. In order to respond to the needs of the customers and maintain relationships with them, companies may develop a new service.

5. When there is a chance in the market that organization can use the opportunity of competitors exit for attracting their customers.

\section{New Service Development's Targets}

NSD can provide two main goals:

1. Business goals

2. Individual goals 
The business goals are those intended to meet the supply goals, and personal goals are those take a step toward fulfilling the goals of individuals who are involved in the development of new services.

\section{Business Goals of NSD}

In the financial services sector (for example banking), the business goals of new service development can include increasing the profitability of other products, attract new customers, improve the loyalty of current customers and providing a platform for new services in the future by opening new markets and changing the company's image (Easingwood and Percival, 1990).

Numerous product and service development in the financial services sector are defensive in nature (Drew, 1995b), and the opportunity cost of the introduction of a new service or product is very high (Haaroff, 1983).

Customers are increasingly inclined to use multiple financial institutions to meet their financial needs, and because of this customers loyalty in the financial services sectors is declining. Hence NSD is considered as an important issue (Moutinho and Brownlie, 1989).

Through increasing the statistics of satisfied customers, a new service can enhance the overall customer satisfaction. Satisfied customers will introduce the new service to the others and are willing to pay higher prices (Reicheld and Sasser, 1990).

Developing new services could also lead to a better understanding of the requirements of specific markets and make the new opportunities exploration much more easier (Easingwood and Percival, 1990).

\section{Individual Goals of NSD}

Little research on the relationship between personal aspirations of the managers involved in the development of new services has been performed. Griffin and Page (1993) found out that middle managers goals and aspirations about new service development is defers from top executive managers.

In the first place, Top-level executives seek to prevent the failure of product development in development of new services process. They also found out that managers mostly try to focus on financial, sales and return on short-term investment. In addition, managers are interested in how they can develop the NSD projects in terms like team performance and satisfaction of employee involved in development.

\section{Key Concepts for New Service Development}

The review of literature on new service development process revealed ten key themes that are as follows: 1) Individuals engaged in NSD process, 2) Learning orientation, 3) New service launch preparation, 4) Full launch, 5) service marketability, 6) Financial performance.

\section{Individuals}

As previously mentioned, individuals participation in NSD is vital. There are four groups of people that must be well managed in new service development projects:

1. Development Employees

2. Frontline Employees (employees who are in contact with customers)

3. Cross-Functional team

4. Customers

Lack of experienced and skilled employees is one of the main obstacles in the new product development process (Drew, 1995a). It is emphasized that adequate compensation should be considered for development activities (Atuahene-Gima, 1996a). Also, there should be no fear of failure. Several service companies take project teams and product heroes approach, which plays an important role in pushing the development process.

\subsection{Frontline Employees}

The second group of employees who are directly involved in the process of NSD are frontline employees. Schneider and Brown (1984) identified four benefits for frontline employee's participation in NSD, which are as follows:

1. Help to identify customer requirements.

2. Employee participation increases the likelihood of a positive run.

3. Stop the overwhelming considerations and help customer needs being provided effectively.

4. Can lead to better customer assistance on behalf of employees.

The role of the frontline employees should not be overlooked (Tajeddini \& Trueman, 2008b). Frontline employees have a unique position because they actively observe the customer respond to the services, which are provided by the company and delivery process. Their constant interaction with customers, gives them a strong sense about what feeling do the customers have about the main services of the company and supportive services of the government. As a result, frontline employees are a wonderful source of ideas for developing services and sometimes make radical innovations in services. 
Their fundamental role in service delivery makes them susceptible to help to develop, analyze service process and design marketing programs (Horace and Hartline, 2010).

\subsection{Cross-Functional team}

Cross-functional team has the responsibility of the early stages of the new service development and usually consists of 3 to 5 persons (Papastathpoulou et al, 2001). The multidisciplinary and multitasking approach in NSD is an important way for using diversity and as an intellectual source to facilitate idea and knowledge sharing across the functional boundaries of organization (Froehle and Roth, 2007). Cross-functional team, also has an interaction and communication coordination role with shareholders who has key roles in development and implementation of new service development during its development process.

In addition, innovation in new products is positively affected by the risk taking authority which has been given to the crossfunctional team (Sethi et al, 2001). Utilizing cross-functional teams in NSD development is positively impact on the effectiveness of the process and will increase the service innovation (Froehle et al, 2000).

\subsection{Customers}

Two prominent features of NSD are customers and intangibility. Hence no physical object exchanged in service industries (intangibility) and service providers must participate the customers in their activities (Dolfsma, 2004; Ennew \& Binks, 1996). As a result, the customers take an active role in new service processes that can be conducive to the innovation process in service industries (Tajeddini, 2011).

Previous researches indicate that companies use customers in the early stages of the new service development in order to get a correct comprehension of service idea and make a thorough assessment of provided service before its full launch (Alam, 2002). New service ideas that are created by the customers have higher utilization value than the ideas which created by the internal development staff, and customer participation in idea generation improves the service marketability through contributing the company in forecasting and responding to the customer needs (Magnusson, et al, 2003).

Customer input throughout the process of NSD and customer's feedbacks will help the top managers to easily determine the acceptable levels of service quality (such as: number of employees, size of facility and service plans, etc.) to achieve the desired quality of service (Horace and Hartline, 2010). Alam (2002) showed that when the top managers involved the customers in the service testing and its experiment stages, he or she will make the final changes after observing the real interaction of customers with new service.

\section{NSD and Learning Orientation}

Learning orientation is one of the most valuable resources for success in global competition because it affects the ability of an organization to compete in the market (Baker \& Sinkula, 1999). The significance of this approach is justified by the substantial knowledge that it provides (Tajeddini, 2009). Learning development takes place in various levels of individual, team and organization and is known as one of the main factors for the human economic welfare (Sullivan, 2000).

HennigThurau and Thurau (2003) indicated that learning orientation is the incessant tendency of employees for developing and enhancing their skills and knowledge. The learning orientation is reflected in the employees strives for increasing their social and technical skills, thus learning is a new and better way for having interaction with customers (HennigThurau and Thurau,2003).

Baker and Sinkula (1999) showed that learning styles (productive or adaptive learning), firstly impact on the innovation and then could influence the success of new product. Hence we can say that learning is a continuous and long-term process and it requires ongoing learning and participation of the employees to fulfill the innovation. Continuous learning makes the new service development staff to learn for the past and provide a basis for new and emerging strengths. Such information should be preserved and be shared in different industries new service development (Tajeddini, 2011).

\section{NSD Launch Preparation}

Horace et al (2010) emphasize that that for new service projects," Launch preparation is important. We must avoid failures in service delivery, and need a good (customer) experience for repatronage."

Launch preparation-involves effective preparation of expert and enthusiastic customer-contact staff prior to product launch, building commitment of employees to deliver superior service quality, and extensive testing of service, process, and IT systems and marketing program designs (Horace and Hartline, 2010).

\section{NSD Full Launch (or Implementation)}

After process and program design and pilot testing, the firm proceeds to full launch of the new service. The firm will gather feedback from external and internal sources to evaluate the launch implementation, market reaction to the new offer, level of utilization, revenue, costs, and profitability. Based on the post launch evaluation, the firm may choose to maintain, modify, or cancel the new moving service (Horace and Hartline, 2010).

Launch implementation is considered as the most important step in new service development (Schneider and Bowen, 1984). Shostack (1984) divide the launch (implementation) into three stages:

1. Operational plans implementation 


\section{Communication strategies implementation}

3. Market introducing

During the implementation stage extensive experiments and training is required (Scheuing and Johnson, 1989). Training should not just limited to the service employees, because the customers also need to know that how they can use the service innovation, and for that communications can play a vital role in controlling customer expectations about new service(Edvardsson and Olsson, 1996).

Before new service introduction to the market, pilot marketing is required, and error correction at this stage of service design process is cheaper and easier than full launch stage. For example Langeard et al (1986) consider pilot marketing more important than market research, because the research doesn't provide reliable means of assessing consumer acceptance of new service. Although. The research offers a vast reflex from the customers, it is recognized important for evaluating customer service experience and make sure that the services are working well. Rather than pilot marketing, banks provide communities and insurance companies to introduce the new services with low promotion. Financial losses resulting from service failure is the cost of lower product test, and because, coping from the service is easy for the competitors that can be done through the information which are obtained from the pilot marketing. Most of the new services are copied in a short time. And between all of these the speed of implementation is important. Market reaction to the reduplication can easily be estimated, and minor differences exist between pilot marketing and complete introduction of product.

\section{NSD and Financial Performance}

Riel and Lievens (2004) claim that investment in NSD tend to be extravagant, and Varadarajan and Jayachandran (1999) observed that the success of new services may provide a powerful market position, but they also state that this is not sufficient to justify the investment. Similarly, Cooper and Edgett (1996) emphasized that many of the NSD failures in meeting expectations have a high relationship with financial performance and value creation for the customers. However, Matear et al (2004), John and Stewart (1998) argued that in order to achieve the relationship between positional advantage and success of new services, financial performance needed to be considered.

Menore and Ruth (2008) by using statistical data found out the relationship between new service development competence and financial criteria, including company's return on investment in retail banking section, and the fact that the impact of NSD on subsequent performance of the hotel business is unknown. Ottenbacher (2001) in an exploratory research with the new service development managers of Germany found out that most of the NSD processes accompanied with some improvements and revisions to the existing service.

\section{New Service Marketability}

New service attempt to provide a fantastic package of core performance features and support systems that being familiar with the product or ease of learning to how to use it, product quality, and Brand effective communication frontline employees expertise and extensive distribution system compose it.

Magnusson et al (2003) indicated that new service ideas, which generated by the customers, have more practical value than the ideas generated by the organizational internal development employees, and customer participation in idea making, improves the service marketability through helping the company in anticipating and responding to the customer needs.

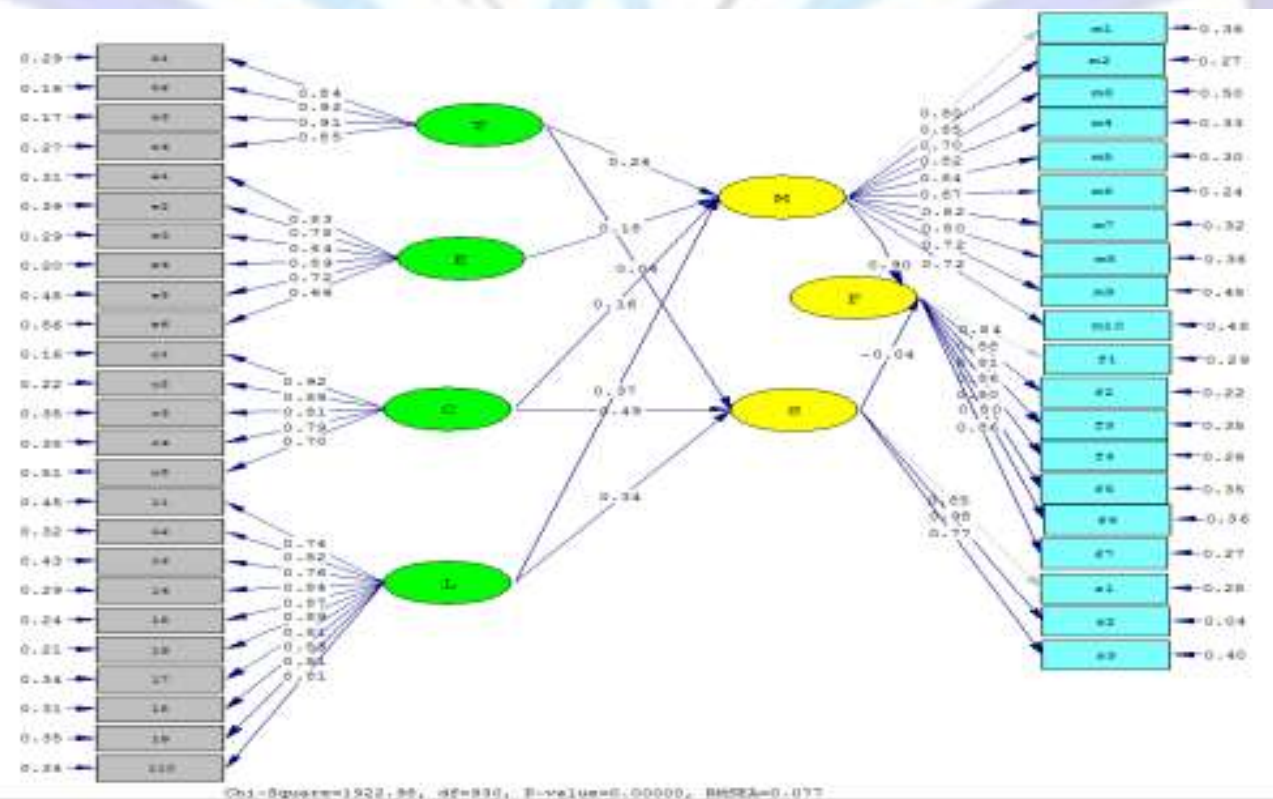

*Note. $T=$ cross-functional teams; $E=$ front-line employees; $C=$ customer involvement; $L=$ learning orientation;

$M=$ new service marketability; $S=$ new service launch preparation; $F=$ new service financial perform 
Figure 1: Structural model of research in standard loading factor mode

After estimating the model parameters, in order to show that how far the model is consistent with the data we review model fitness. LISREL software provides numerous indicators for surveying the model fitness that are absolute, incremental and parsimonious fit (Hair et al, 2010). The model fitness indicators value with their permissible limit has been provided in Table 2.

Table 2: The model fitness indicators results

\begin{tabular}{|l|l|l|l|l|l|}
\hline Index & X2 & RMSEA & GFI & NFI & AGFI \\
\hline Permissible Limit & $<3$ & $0.03-0.08$ & $0-1$ & $0-1$ & $0-1$ \\
\hline Model Estimation Value & 1.96 & 0.077 & 0.58 & 0.93 & 0.53 \\
\hline
\end{tabular}

By looking at the results of the fitness indicators and considering their permissible limit in table 2, we conclude that the model has a good fitness.

\section{RESEARCH METHOD}

In terms of research classification, the research is practical and in terms of data collection methods, it is descriptive of correlation based on structural equations. The data-gathering tool is questionnaire, which includes 45 questions to survey the views of statistical population and analyze them. Range used in the study is Likert range.

In this study, 150 questionnaires were distributed and collected that by eliminating waste and biased ones, 118 questionnaires are selected for analysis. In the questionnaires analysis, descriptive and inferential analyses are used. Descriptive analysis includes frequency tables and mean, inferential analysis includes factor analysis, structural equation modeling and path analysis. Software used for data analyses are SPSS version 20 software and LISREL version 8.8 software.

Statistical population includes managers, marketing, information technology and research and development experts of banks in both branches and headquarters level throughout the city of Tehran. Due to unlimited sample size, Quota sampling has been used.

Table 3: Summary of statistical test of reliability and validity of research variables results

\begin{tabular}{|c|c|c|c|c|c|c|c|}
\hline Index & $\mathrm{T}$ & $\mathrm{E}$ & $\mathrm{C}$ & $\mathrm{L}$ & $\mathrm{M}$ & $\mathrm{S}$ & $\mathrm{F}$ \\
\hline $\begin{array}{c}\text { Cranach's } \\
\text { Alpha }\end{array}$ & 0.930 & 0.907 & 0.907 & 0.953 & 0.944 & 0.898 & 0.941 \\
\hline AVE & 0.77 & 0.62 & 0.68 & 0.67 & 0.64 & 0.76 & 0.70 \\
\hline CR & 0.93 & 0.91 & 0.72 & 0.95 & 0.95 & 0.81 & 0.94 \\
\hline $\begin{array}{c}\text { T-Value } \\
\text { Interval }\end{array}$ & $0.84-0.92$ & $0.67-0.89$ & $0.70-0.92$ & $0.75-0.89$ & $0.70-0.87$ & $0.78-0.97$ & $0.80-0.88$ \\
\hline
\end{tabular}

${ }^{*}$ Note. $\mathrm{T}=$ cross-functional teams; $\mathrm{E}=$ front-line employees; $\mathrm{C}=$ customer involvement; $\mathrm{L}=$ learning orientation= new service marketability; $\mathrm{S}=$ new service launch preparation; $\mathrm{F}=$ new service financial performance.

Table 4: The research hypotheses results

\begin{tabular}{|l|l|l|l|}
\hline Research hypotheses & $\begin{array}{l}\text { Path } \\
\text { Coefficient }\end{array}$ & T-Value & Result \\
\hline $\begin{array}{l}\text { The impact of cross-functional teams on } \\
\text { new service marketability }\end{array}$ & 0.24 & 2.95 & Approved \\
\hline $\begin{array}{l}\text { The impact of cross-functional teams on } \\
\text { new service lunch preparation }\end{array}$ & 0.04 & 0.051 & Disapproved \\
\hline $\begin{array}{l}\text { The impact of front-line employees on } \\
\text { new service marketability }\end{array}$ & 0.18 & 1.91 & Disapproved \\
\hline $\begin{array}{l}\text { The impact of customer involvement on } \\
\text { the new service marketability }\end{array}$ & 0.16 & 1.77 & Disapproved \\
\hline $\begin{array}{l}\text { The impact of customer involvement on } \\
\text { the new service launch preparation }\end{array}$ & 0.49 & 5.18 & Approved \\
\hline $\begin{array}{l}\text { The impact of learning orientation on the } \\
\text { new service marketability }\end{array}$ & 0.37 & 3.72 & Approved \\
\hline $\begin{array}{l}\text { The impact of learning orientation on the } \\
\text { new service launch preparation }\end{array}$ & 0.34 & 3.54 & Approved \\
\hline
\end{tabular}




\begin{tabular}{|l|l|l|l|}
\hline $\begin{array}{l}\text { The impact of new service marketability } \\
\text { on the new service financial } \\
\text { performance }\end{array}$ & 0.90 & 8.66 & Approved \\
\hline $\begin{array}{l}\text { The impact of new service launch } \\
\text { preparation on the new service financial } \\
\text { performance }\end{array}$ & -0.04 & -0.56 & Disapproved \\
\hline
\end{tabular}

Content validity gained by using the approved form of questions. The questionnaire has been approved by 8 academic experts view and bank managers and experts who are associated with various kind of bank services, Construct validity (CR) which is a convergent validity indicator has been calculated for each construct and summarized in table 3 , shows that all of the research constructs have high validity. AVE has also been used as a statistical test which for all the structures it is higher than 0.50 . To check the reliability of the research, the cronbach's alpha is used. Table 3 summarizes the results of statistical tests of reliability and validity. Based on the results of statistical tests, the measuring instrument, which used for measuring different variables, has a very high reliability and required conditions.

\section{CONCLUSION}

In the study, new service development modeling and factors affecting its financial performance in banking industry of Iran have been surveyed. The research main purpose was to define the effect of NSD factors on its financial performance in banking industry.

The result shows, Cross-functional teams are effective on NSD marketability. The results of research are consistent with research findings of (Melton and Hartline, 2010). In contrary with Melton and Hartline (2012) research findings, results show that the cross-functional teams have no effect on the NSD launch preparation. Front-line employees impact on the NSD marketability has not been approved which is complied with Melton and Hartline (2010) it also is in contrast with Melton and Hartline (2013) and Schneider and Bowen (1984) researches. Customer involvement impact on NSD marketability has not been approved with is complied with Melton and Hartline (2010) findings and in contrast with Von Hippel (2001) and Lagrosen (2005). But on the other, results show that customer involvement is effective on the NSD launch preparation which also has been approved in (Melton and Hartline,2010; Cheng et al,2012; singular,2011;kristenson et al ,2008; and Chalketi, 2007). About the learning orientation, the results show that it is effective on NSD marketability that is also approved in (Melton and Hartline,2013; Sethi et al,2001; Edmanson and Nembhard,2009; Calantone et al,2002), and it also has positive impact on NSD launch preparation just as (Sethi et al,2001; Edmanson and Nembhard,2009) findings shows. Regarding the NSD marketability impact on the new service development financial performance, result shows that it has positive impact on NSD financial performance which is similar to Cooper and Edgett (1996) findings. At last in contrast with our expectations before research performance, the study results shows that NSD launch preparation is not effective on NSD financial performance.

\section{RECOMMENDATIONS FOR FUTURE RESEARCH}

The Impact of NSD launch preparation on NSD financial performance should be executed in other countries with different banking systems and industries, and the research results could be compared for better understanding the cause of this result.

Other influencing factors on NSD such as Market orientation, business partners (like shareholders) could be considered in the organizational context, which supports continuing learning, flexibility, delegating authority and power to teams and risk taking for future studies.

The present study has been conducted in the banking industry, so it is proposed that in the future researches the research model to be surveyed in other financial institutions and organizations, which makes the researcher able to compare the study, results. And finally it is necessary to conduct a more comprehensive empirical study in order to provide an integrated model of NSD process, participants and culture.

This study showed that viral marketing is low cost but has high impact on the viable investment. Therefore, in addition to other marketing components a special attention should be on this because it is the most important factor influencing brand equity.

\section{ACKNOWLEDGMENTS}

I would like to thank from banking corporations such as Eghtesad Novin (EN), Pasargad, Parsian, Day, Tourisim, Saderat, Export Development, Saman and Tejarat banks for their kind consideration on this research and their cooperation in data collection. 


\section{REFRENCES}

[1] Menor, Larry J. Tatikonda, Mohan V. Sampson, Scott E. (2002). New Service Development: Areas for Exploitation and Exploration. Journal of Operations Management, Vol. 20, pp. 135-157.

[2] Zeithaml, Valarie A., and Mary Jo Bitner 2000, "Services marketing: integrating customer focus across the firm" (2 ed.). Boston: Irwin/McGraw- Hill.

[3] Edvardsson, B., Enquist, B. and Hay, M. (2006), "Values based service brands: narratives from IKEA", Managing Service Quality, Vol. 16 No. 3, pp. 230-46.

[4] De Brentani, U. 1991. Success Factors in Developing New Business Services.European Journal of Marketing, 25, 33 59.

[5] Dalton, D., Todor, W. and Krackhardt, D. (1982), "Turnover overstated: the functional taxonomy", Academy of Management Review, Vol. 7 No. 1, pp. 117-23.

[6] Shekar, A. (2007). "An Innovative Model of Service Development: A process guide for service managers". The Innovation Journal: The Public Sector Innovation Journal, 12(1), 2-20.

[7] Howells, J. (2000) Innovation \& Services: new conceptual frameworks. University of Manchester, CRIC discussion paper no 38, August.

[8] Lovelock, C.H., 1984. "Developing and implementing new services". In: George, M. (Ed.), Developing New Services. American Marketing Association, Chicago, IL, pp. 44-64.

[9] Avlonitis, G. J., Papastathopoulou, P. G. \& Gounaris, S. P. 2001. An empirically based typology of product innovativeness for new financial services: Success and failure scenarios. Journal of Product Innovation Management, 18, 324- 342.

[10] Van der Aa, W. and Elfring, T. (2002) Realizing innovation in services. Scandinavian Journal of Management,18, 155171.

[11] Alam, I. 2006. "Service innovation strategy and process: a cross-national comparative analysis". International Marketing Review, Vol. 23 ,No .3, pp. 234-254.

[12] Johnson, S.P., Menor, L.J., Roth, A.V., Chase, R.B.,( 2000). "A critical evaluation of the new service development process: integrating service innovation and service design. In: Fitzsimmons, J.A.,Fitzsimmons, M.J. (Eds.), New Service Development-Creating Memorable Experiences". Sage Publications, Thousand Oaks,CA,1-32.

[13] Sigala, M. and Chalkiti, K. (2007a), "New service development: preliminary findings on process development and assessment from the Greek hotels", Advances in Hospitality Leisure, Vol. 3, pp. 129-49.

[14] Johne, Axel, and Chris Storey. 1998, "New Service Development: A Review of the Literature and Annotated Bibliography", European Journal of Marketing, Vol. 32, No. 3/4, pp. 184-251.

[15] Goldstein SM, Johnston R, Duffy J, et al. 2002. "The service concept: the missing link in service design research?" Journal of Operations Management, 20 (2), 121-134 Sp. Iss.

[16] Palmer, A. (2001). Principles of services marketing. Maidenhead, England: McGraw-Hill.

[17] Easingwood, C. and Percival, I (1990) "Evaluation of New Financial Services ", International Journal of Bank Marketing, 8, 6, pp. 3-8.

[18] Drew, S. 1995. "Strategic benchmarking: innovation practices in financial institutions", International Journal of Bank Marketing, Vol. 13 No. 1, pp. 4-16.

[19] Haaroff K. (1983). "An exercise in product development for 1980s: International cash management service. "International Journal of Bank Marketing, 1(3), 56-68.

[20] Moutinho, L., \& Brownlie, D.T. 1989. "Customer satisfaction with bank services: a multidimensional space analysis". International Journal of Bank Marketing, Vol. 7, No. 5, pp. 23-7.

[21] Reichheld, Frederick, and Sasser, W. Earl. 1990. "Zero Defections: Quality Comes to Services", Harvard Business Review, September/October.

[22] Easingwood, C. and Percival, I (1990) "Evaluation of New Financial Services ", International Journal ofBank Marketing, 8, 6, pp. 3-8.

[23] Griffin, A., A. L. Page. 1993. An interim report on measuring prod- uct development success and failure. J. Product Innovation Management 10(4) 291-308.

[24] Atuahene-Gima, K. (1996), "Market orientation and innovation”, Journal of Business Research, Vol. 35 No. 2 , pp. 93 103. 
[25] Schneider, Benjamin and David Bowen (1984), "New Service Design, Development and Implementation and the Employee," in Developing New Services, William R. George and Claudia Marshall E. eds. Chicago, IL: American Marketing Association, pp. 82-101.

[26] Tajeddini, K., \& Trueman, M. 2008b. "The potential for innovativeness: A tale of the Swiss watch industry". Journal of Marketing Management, Vol. 24, pp. 169-184.

[27] Horace L. Melton and Michael D. Hartline (2010), "Customer and Frontline Employee Influence on New Service Development Performance", Journal of Service Research, Vol. 13, No. 4, pp. 411-425.

[28] Avlonitis, G. J., Papastathopoulou, P. G. \& Gounaris, S. P. 2001. An empirically based typology of product innovativeness for new financial services: Success and failure scenarios. Journal of Product Innovation Management, 18, 324- 342.

[29] Froehle, Craig M. and Aleda V. Roth (2007), "A Resource-process Framework of New Service Development," Production and Operations Management, Vol. 16, No. 2, pp. 169-188.

[30] Sethi, Rajesh, Daniel C. Smith, and C. Whan Park (2001), "Cross-functional Product Development Teams, Creativity, and the Innovativeness of New Consumer Products," Journal of Marketing Research, Vol. 38, No. 1, pp. 73-85.

[31] Froehle, Craig M. Richard B Chase. and Christopher A. Voss (2000), "Antecedents of New Service Development Effectiveness: An Exploratory Examination of Strategic Operations Choices," Journal of Service Research, Vol. 3, No. 1, pp. 3-17.

[32] Dolfsma, W. 2004. The process of new service development - issues of formalization and appropriability. International Journal of Innovation Management 8(3) 319-337.

[33] Ennew, C. T. \& Binks, M. R. (1996). Good and bad customers: The benefits of participating in the banking relationship. International Journal of Bank Marketing, Vol.14, No. 2, pp. 5-13.

[34] Tajeddini. K. 2011. "The effects of innovativeness on effectiveness and efficiency." Education, Business and Society: Contemporary Middle Eastern Issues, Vol. 4 ,No. 1, pp. 6- 18.

[35] Alam, Ian (2002), "An Exploratory Investigation of User Involvement in New Service Development," Journal of the Academy of Marketing Science, Vol. 30, No. 3, pp. 250-261.

[36] Magnusson, Peter R. Jonas Matthing, and Per Kristensson (2003), "Managing User Involvement in Service Innovation: Experiments with Innovating End Users," Journal of Service Research, Vol. 6, No. 2, pp. 111-124.

[37] Baker, W.E. and Sinkula, J. 1999a. "The synergistic effect of market orientation and learning orientation on organizational performance", Journal of the Academy of Marketing Science, Vol. 27 No. 4, pp. 411-27.

[38] Tajeddini, Kayhan. 2009. "The Impact of Learning Orientation on NSD and Hotel Performance: Evidence from the Hotel Industry in Iran," Education, Business and Society: Contemporary Middle Eastern Issues, Vol. 2No. 4, pp. 262 275.

[39] Sullivan, R. 2000. "Entrepreneurial learning and mentoring". International Journal of Entrepreneurial Behaviour \& Research, Vol. 6, pp. 160-172.

[40] Hennig-Thurau, T., \& Thurau, C., 2003. "Customer orientation of service employees- Toward a conceptual framework of a key relationship marketing construct". Journal of Relationship Marketing, Vol.2, No. 1/2, pp. 23-41.

[41] Baker, W.E. and Sinkula, J. 1999b, "Learning orientation, market orientation, and innovation: integrating and extending models of organizational performance", Journal of Market Focused Management, Vol. 3 No. 4, pp. 295-308.

[42] Shostack, G.L. 1984a, "Designing services that deliver”, Harvard Business Review, January- February, pp. 133-9.

[43] Scheuing, E.E. and Johnson, E.M. 1989b. "A proposed model for new service development", Journal of Services Marketing, Vol. 3, No. 2, pp. 25-34.

[44] Edvardsson, Bo, and Jan Olsson (1996), "Key Concepts for New ServiceDevelopment," The Service Industries Journal, Vol. 16, No. 2, pp. 140-164.

[45] Langeard, E., Reffait, P., Eigler, P. (1986), "Developing new services", in Venkatesan, M., Schmalensee, D.M., Marshall, C. (Eds), Creativity in Services Marketing, American Marketing Association, Chicago, IL,.

[46] Van Riel, Allard C. R., and Annouk Lievens. 2004, "New service development in high tech sectors: A decision-making perspective", International Journal of Service Industry Management, Vol. 15, No. 1, pp. 72-101.

[47] Varadarajan, P. R., \& Jayachandran, S. 1999. "Marketing strategy: An assessment of the state of the field and outlook". Academy of Marketing Science Journal ,Vol. 27, pp.120-143.

[48] Cooper, R.G., Edgett, S.J. 1996. "Critical success factors for new financial services", Marketing Management, Vol. 5, No. 3, pp.26-37. 
[49] Matear, S., Grey, B. J. and Garrett, T. 2004. "Market orientation, brand investment, new service development, market position and performance for service organizations". International Journal of Service Industry Management, Vol. 15 No. 3, pp. 284-301.

[50] Menor, L. J. \& Roth, A. V. (2008). New service development competence and performance: An empirical investigation in retail banking. Production and Operations Management Society, Vol.17, pp. 267-284.

[51] Ottenbacher, M. 2001. "New service development in the hospitality industry: An exploratory study". Paper presented at the 2001 Conference of the Australian and New Zealand Marketing Academy (ANZMAC 2001), Massey University, Albany, Auckland, New Zealand. Retrieved from http://smib.vuw.ac.nz:8081/WWW/ ANZMAC2001/anzmac/AUTHORS/pdfs/Ottenbacher.pdf

[52] Hair, J.F., Black, W.C., Babin, B.J., \& Anderson, R.E. (2010). Multivariate Data Analysis. Seventh Edition. Prentice Hall, Upper Saddle River, New Jersey.

[53] Horace, L. Melton \& Michael D. Hartline (2012)," Employee Collaboration, Learning Orientation, and New Service Development Performance," Journal of Service Research, Vol. 16, No. 1, pp. 67-81.

[54] Von Hippel, E. (2001). Perspective: User Toolkits for innovation. Journal of Product Innovation Management, 18(4), 247-57.

[55] Lagrosen, S. (2005), "Customer involvement in new product development: a relationship marketing perspective", European Journal of Innovation Management, Vol. 8 No. 4, pp. 424-36.

[56] Cheng, C.C. and Krumwiede, D. (2012), "The role of service innovation in the market orientation - new service performance linkage", Technovation, Vol. 32 Nos 7-8, pp. 487-497.

[57] Kristensson, P., Matthing, J. and Johansson, N. (2008). "Key strategies for the successful involvement of customers in the co-creation of new technology-based services." International Journal of Service Industry Management, Vol. 19 No. 4, pp. 474-491.

[58] Edmondson, Amy C. and Ingrid M. Nembhard (2009), "Product Development and Learning in Project Teams: The Challenges Are the Benefits," Journal of Product Innovation Management, Vol. 26, No. 2, pp. 123-138.

[59] Garcia, Rosanna and Roger Calantone. 2002. "A critical look at technological innovation typology and innovativeness terminology: a literature review”, Journal of Product Innovation Management, Vol. 19, No. 2, pp. 110-32.

\section{Author' biography with Photo}

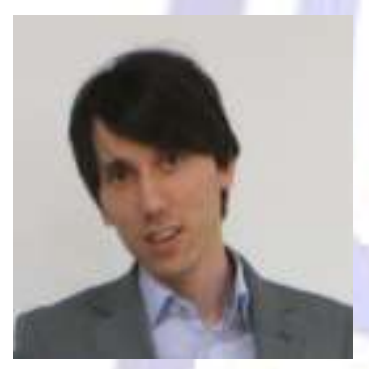

NAME: Shahram Ghahramani

Marital Status: Single

Date of Birth: December 29,1989

Contact Address: Block 25,3rd floor, No.1402, Parsin Complex, Sharyati Ave., Tehran,Iran.

Telephone: (+98) 9125619613

E-mail: sh.ghahramani@imps.ac.ir; shahrambusiness2020@gmail.com

Areas of Specialization: Marketing, Business, Brand Management SME's, International

Entrepreneurship.

Experiences:

- Business manager of radin parsa iranian (r.p.i) Co. (Nov $1^{\text {st }}, 2014$ - Now)

- Directorate advisor of International Affairs in Hafez Insurance co. (Jan $1^{\text {st }}, 2014$, Now)

- Expert of foreign currency services, Eghtesad Novin (EN) bank. (Apr $24^{\text {th }}-$ Nov $\left.1^{\text {st }}, 2014\right)$

- Expert of international department Eghtesad Novin (EN) bank. (Jan $1^{\text {st }}, 2012-$ Apr $\left.24^{\text {th }}, 2014\right)$

- English master Aryanpour School of Culture and Education. (Feb $2^{\text {nd }}, 2013$ - Now).

\section{Education:}

- Master of Marketing, Institute for management and planning studies (IMPS), NO.6, shahid mokhtar ASKARI (JAMAL abad) st., north angel of niavaran castle., TEHRAN, IRAN

- Bachelor of Business Administration, Payame Noor University, POB: 19395-4697, Lashkarak Road, Tehran, I. R. IRAN

\section{Published Papers:}

1. Rezvani, M., Ghamari, Y., Ghahramani, SH, " Identifying Themes of Entrepreneurial Strategy of New Ventures in International Markets Entry", Journal of Economics, Business and Management, Vol. 1, No. 2, April 2013. 
2. Rezvani, M., Rafati, S., and Ghahramani, SH, "Study of Effective Factors on the Evaluation of Re-export in Iran through Analysis of Network Process", Proceedings of 4th Asia-Pacific Business Research Conference 30 September - 1 October 2013, Bayview Hotel, Singapore, ISBN: 978-1-922069-31-3.

3. Aghaei, M., Asadollahi, A., Sadat Hosseini, R., Javani, M., and Ghahramani, SH, " The Impact of Store Brand Price -Image on Retailer Equity Dimensions among the Customers of Etka Chain Stores of Tehran", J. Basic. Appl. Sci. Res., 3(5)873-879, 2013.ISI Journal.

4. Rezvani, M., Ghahramani, SH., Kiaee, K, "An Investigation of Viral Marketing Effects on Costumer-Based Brand Equity In Mobile Market", Middle-East Journal of Scientific Research 18 (3): 376-381, 2013, ISSN 19909233. ISI Journal.

5. Rezvani, M., Shariatmadari, S.M.H., Ghahramani, SH, "International Entrepreneurial Opportunity: A metasynthesis of Previous Researches", 2nd International conference on Management, Leadership and Governance (ICMLG14), Babson University, 2014.

His ability in speaking four international languages such as: English, Turkish, Persian in Native accent and some Russian have given him so many chances and ability for his communication with national and international researchers, Managers and businessmen especially in Middle East. 